www.czasopisma.marszalek.com.pl/pl/10-15804/npw

Natalia Matiaszczyk

Uniwersytet Łódzki

ORCID: https://orcid.org/0000-0003-1310-0732

\title{
Długa droga do wolności - problemy adaptacyjne północnokoreańskich uciekinierów w Korei Południowej
}

\section{The long way to freedom - adaptation problems of North Korean defectors in South Korea}

\section{Abstract}

Although South Korea and North Korea have shared a common national and cultural heritage for thousands of years, they have become de facto stranger to each other in the last few decades. They differ not only in a different political and economic system, but also in the mentality and lifestyle of ordinary citizens, and in language. Since the 1990s, the number of North Korean defectors has increased. Those who decide to escape to South Korea encounter many problems in their new homeland. The aims of this article is to present the main adaptation problems faced by North Korean defectors, such as trauma, discrimination and problems with assimilation in South Korean society. There are also shown the examples of how to overcome or reduce them, as well as what support from the South Korean authorities looks like.

Keywords: North Korean defectors, identity, adaptation, South Korea, migrants 


\section{Долгий путь к свободе - проблемы адаптации северокорейских перебежчиков в Южной Корее}

\section{Аннотация}

Хотя Южная Корея и Северная Корея имеют общее национальное и культурное наследие, которое формировалось на протяжении тысячелетий, за последние несколько десятилетий они фактически стали чужими друг другу. Оба государства отличаются не только политической и экономической системой, но и менталитетом, и образом жизни обычных граждан, а также языком. С 1990-х годов количество перебежчиков из Северной Кореи увеличилось. Те, кто решается бежать в Южную Корею, сталкиваются со множеством проблем на своей новой родине. Цель данной статьи - представить основные проблемы адаптации, с которыми сталкиваются перебежчики из Северной Кореи, такими как травмы, дискриминация и проблемы с ассимиляцией в южнокорейском обществе. Также показаны примеры преодоления таких препятствий и то, как выглядит поддержка со стороны властей Южной Кореи.

Ключевые слова: северокорейские перебежчики, идентичность, приспособление, Южная Корея, мигранты

\section{Wstęp}

Dółwysep Koreański - miejsce zamieszkiwane przez jeden naród, sztucznie _ podzielony na dwa państwa od 70 lat $^{1}$. I choć Korea Południowa oraz Korea Północna dzielą wspólne dziedzictwo narodowe i kulturowe od tysięcy lat ${ }^{2}$, to przez ostatnie kilkadziesiąt stały się dla siebie de facto obce. Różni je nie tylko inny system polityczny i gospodarczy, ale także mentalność i styl życia zwykłych obywateli oraz, co staje się coraz bardziej widoczne, język, choć zarówno na Południu i na Północy używa się oficjalnie tego samego języka - koreańskiego.

Różnice pomiędzy obiema Koreami zaczęły się jeszcze bardziej powiększać na początku lat 90. XX wieku. Wtedy też południowokoreański rząd przyjął politykę Segyehwa (pol. Globalizacja), która zakładała znaczące

1 Zarówno Korea Południowa, jak i Korea Północna ogłosiły niepodległość w 1948 roku - odpowiednio 15 sierpnia i 9 września.

2 Według koreańskich podań legendarnym założycielem Korei był Dangun, który w 2333 roku p.n.e. miał stworzyć państwo Gojoseon. 
otwarcie krajowego rynku na zagranicznych inwestorów oraz gospodarkę światową (Park, 1996). To pociągnęło za sobą rozwój turystyki, komercjalizację, większy dostęp do innych kultur, adaptowanie zagranicznych zwyczajów czy słownictwa (szczególnie z języka angielskiego).

Równocześnie Korea Północna rozwijała swoją politykę izolacji i autarkii (części składowe doktryny Juche ${ }^{3}$ ), odrzucając przy tym wszelkie przejawy globalizacji. Odcięcie obywateli od informacji z całego świata i ich indoktrynacja w połączeniu z terrorem i inwigilacją mają sprawić, że mieszkańcy będą wierni i posłuszni Partii Pracy Korei. Jednak pomimo starań władz i służb Koreańczycy z KRL-D coraz częściej są świadomi, że ich ojczyzna wcale nie jest idealnym miejscem do życia. Próbują oni nielegalnymi sposobami zdobywać informacje na temat sytuacji w sąsiednich krajach czy choćby południowokoreańskie filmy, które są zakazane, ryzykując przy tym więzieniem ${ }^{4}$.W szystko to w połączeniu ze skrajnie niewydolną gospodarką, skupioną na rozwijaniu armii sprawia, że niektórzy obywatele Korei Północnej decydują się na ucieczkę z własnego kraju, by zamieszkać na południe od 38. równoleżnika.

Mieszkańcy, którzy decydują się na ucieczkę z Korei Północnej, mogą opuścić swój kraj poprzez granice z trzema różnymi państwami: z Rosją, gdzie jednak granica przebiega przez końcowy bieg rzeki Tumen, w związku z czym koryto jest bardzo szerokie, więc przeprawa jest trudniejsza; z Koreą Południową przez Koreańską Strefę Zdemilitaryzowaną, jednak z uwagi na jej charakter i ścisłą kontrolę, jedynie pojedyncze osoby próbują się przedostać w ten sposób; oraz z Chinami, z którymi KRL-D ma najdłuższą granicę, a ciągnie się ona wzdłuż koryta rzek Tumen i Yalu. Najwięcej Koreańczyków próbuje uciekać właśnie przez granicę z Chinami. Brak jednak dokładnych danych ile tak naprawdę osób rokrocznie opuszcza nielegalnie swoją ojczyznę i przez które granice. Próby ucieczki podejmują także północnokoreańscy

3 Doktryna polityczna wprowadzona przez Kim Il-sunga (Kim Ir-sena) zakładająca odrzucanie obcych wzorców ideologicznych, pełną niezależność polityczną oraz samowystarczalność ekonomiczną i wojskową.

4 W sondażu przeprowadzonym przez Intermedia w 2017 roku na grupie 350 uciekinierów, uchodźców i podróżujących z Korei Północnej, 92\% z nich stwierdziło, że oglądało zagraniczne treści (seriale, filmy, programy informacyjne) na odtwarzaczu DVD (Hajek, 2017). 
dyplomaci, tacy jak Jo Song-gil (p.o. ambasadora KRL-D we Włoszech) czy Thae Yong-ho (chargé d'affaires ambasady KRL-D w Wielkiej Brytanii), o którym mowa będzie także w dalszej części (Shin, 2020).

Artykuł skupia się jednak wyłącznie na północnokoreańskich uciekinierach, którzy uciekli ze swojego państwa i zamieszkali w Korei Południowej. Ważnym podkreślenia jest to, że artykuł dotyka wyłącznie tych uciekinierów, który widnieją w oficjalnych statystykach południowokoreańskich, tj. zwrócili się o pomoc i ochronę w południowokoreańskich placówkach dyplomatycznych i konsularnych oraz przebywają na terenie Korei Południowej legalnie. Mimo tej samej narodowości i używania (przynajmniej oficjalnie) tego samego języka mają duże problemy z odnalezieniem się w południowokoreańskim społeczeństwie. Proces adaptacyjny można scharakteryzować jako integrację systemów kulturowych i tożsamościowych rozwiniętych w jednym kontekście (tj. środowisku) z nowym kontekstem oraz rozwój więzi z nowym państwem (Sonn, 2002, s. 205). Z kolei południowokoreański proces adaptacyjny to proces, któremu podlegają uciekinierzy z KRL-D na terenie Południa. Jego najważniejsze założenia i elementy są regulowane przez południowokoreański rząd i znajdują się w Ustawie o ochronie i wsparciu w osiedleniu dla północnokoreańskich uchodźców z 1997 roku. 1997 rok jest początkiem zakresu czasowego, jaki obejmuje niniejszy artykuł. Natomiat cezurę końcową wyznacza dzień 1 marca 2021 roku.

Artykuł stara się odpowiedzieć na następujące pytania badawcze: jak wygląda proces adaptacyjny północnokoreańskich uciekinierów w Korei Południowej? Jakie są główne problemy i wyzwania, które oni napotykają, a które związane z przystosowywaniem się do nowego otoczenia? Hipotezę badawczą określono następująco: istnieje wiele barier natury gospodarczej, językowej, polityczno-prawnej czy edukacyjnej, które utrudniają proces adaptacyjny północnokoreańskich uciekinierów w Korei Południowej, choć jednocześnie widać sfery, w których to odnotowują oni pewne sukcesy. By nakreślić charakterystykę i nietypowość zagadnienia północnokoreańskich uciekinierów wykorzystano metodę historyczną oraz metodę komparatystyczną. W kwestii przyszłego rozwoju analizowanej w artykule problematyki zastosowano prognozowanie. Ze względu na kompleksowy charakter omawianego tematu, analizie poddane zostały monografie i artykuły naukowe z zakresu politologii, stosunków międzynarodowych oraz psychologii. 
W odniesieniu do najnowszych wydarzeń informacje czerpano również z portali informacyjnych. Przydatne były także historie Koreańczyków z KRL-D, zamieszczone na platformie YouTube.

\section{Podstawowe informacje dotyczące północnokoreańskich uciekinierów w Korei Południowej}

Od czasu zawieszenia broni w wojnie koreańskiej w 1953 roku, z Korei Północnej uciekło od 100 do 300 tysięcy osób (Life Funds for North Korean Refugees, 2009). Jednak są to jedynie dane szacunkowe, gdyż prawdziwa liczba nie jest znana. Co więcej, jedynie części z nich udaje się dotrzeć do Korei Południowej. Do czasu zakończenia „zimnej wojny” liczba Koreańczyków z Północy, którzy przedostawali się na Południe była dość mała. Wszystko zmieniło się jednak w latach 90. XX wieku. Niewydajna polityka władz centralnych $\mathrm{w}$ połączeniu $\mathrm{z}$ wielkimi powodziami sprawiły, że w KRL-D doszło do klęski głodu, w trakcie której umrzeć mogło około miliona osób (Human Rights Watch, 2006). To ona przyczyniła się do masowych ucieczek z kraju.

Do 1998 roku z KRL-D do Korei Południowej uciekło poniżej tysiąca osób. W latach 2001-2019 na teren Południa trafiło ponad 32,5 tysiąca Koreańczyków z Północy (Ministerstwo Zjednoczenia, 2021a). Od 2006 do 2011 roku, rokrocznie przyjeżdżało ponad 2 tysiące uciekinierów. Jednak od 2012 roku liczba ta drastycznie spadła, choć i tak utrzymuje się na poziomie powyżej tysiąca osób. Wpływ na to miały głównie działania władz Korei Północnej - na granice wysłano więcej żołnierzy oraz zaczęto budować ogrodzenia, które mają utrudnić ucieczkę.

Najwięcej uciekinierów mieszkających obecnie na terenie Korei Południowej pochodzi z prowincji Hamgyong Północny. Dzieje się tak z kilku powodów. Przede wszystkim tereny przygraniczne w wielu miejscach są słabo zaludnione, a koryto rzeki Tumen, która stanowi granicę, szczególnie w rejonach górskich jest łatwiejsze do pokonania. Co więcej, po przekroczeniu granicy z Chinami uciekinierzy znajdują się na terenie prefektury Yanbian. To jednostka autonomiczna, której ok. 38\% mieszkańców stanowią Chaoxianzu, czyli chińscy Koreańczycy (Colin, 2003, s. 1-2). Dlatego też uciekinierom z KRL-D jest tam łatwiej „wtopić się w tłum” i tym samym wzbudzać mniej 


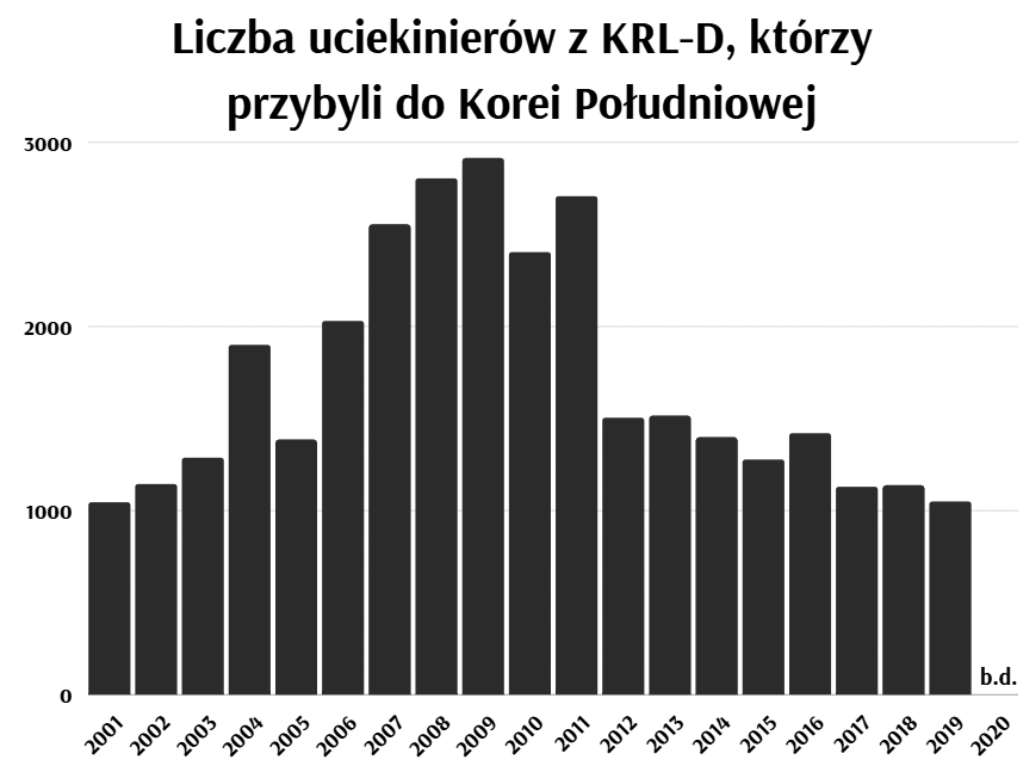

Wykres 1. Liczba uciekinierów z KRL-D, którzy przybyli do Korei Południowej

Źródło: opracowanie własne na podstawie danych Ministerstwa Zjednoczenia Korei Południowej. Pobrane z: https://www.unikorea.go.kr/eng_unikorea/ relations/statistics/defectors/.

podejrzeń wśród funkcjonariuszy chińskich służb. Dokładne dane dotyczące pochodzenia uciekinierów przedstawione zostały na poniższej mapie.

Część uciekinierów zamieszkuje Chiny, gdzie istnieje duża mniejszość koreańska. Jednak co istotne, skazani są wtedy na lata ukrywania się, gdyż uciekinier z KRL-D nie jest traktowany w Chinach jak uchodźca (Choi, 2018, s. 80). Stąd też wynika współpraca chińskiej i północnokoreańskiej policji. Złapany na terenie Chin uciekinier jest deportowany do KRL-D, a tam po przesłuchiwaniu przez Bowibu (północnokoreańska tajna policja) trafia najczęściej do obozu koncentracyjnego. To samo dotyczy Rosji - jeśli Koreańczyk z Północy zostanie złapany przez rosyjskie służby, trafi on z powrotem do swojego kraju. Dlatego też północnokoreańscy uciekinierzy podejmują próby przedostania się do południowokoreańskich ambasad i konsulatów, bo tylko poprzez nie mają możliwość dostania się do Korei Południowej. Wielu 


\section{Liczba północnokoreańskich uciekinierów (podział na prowincje)}

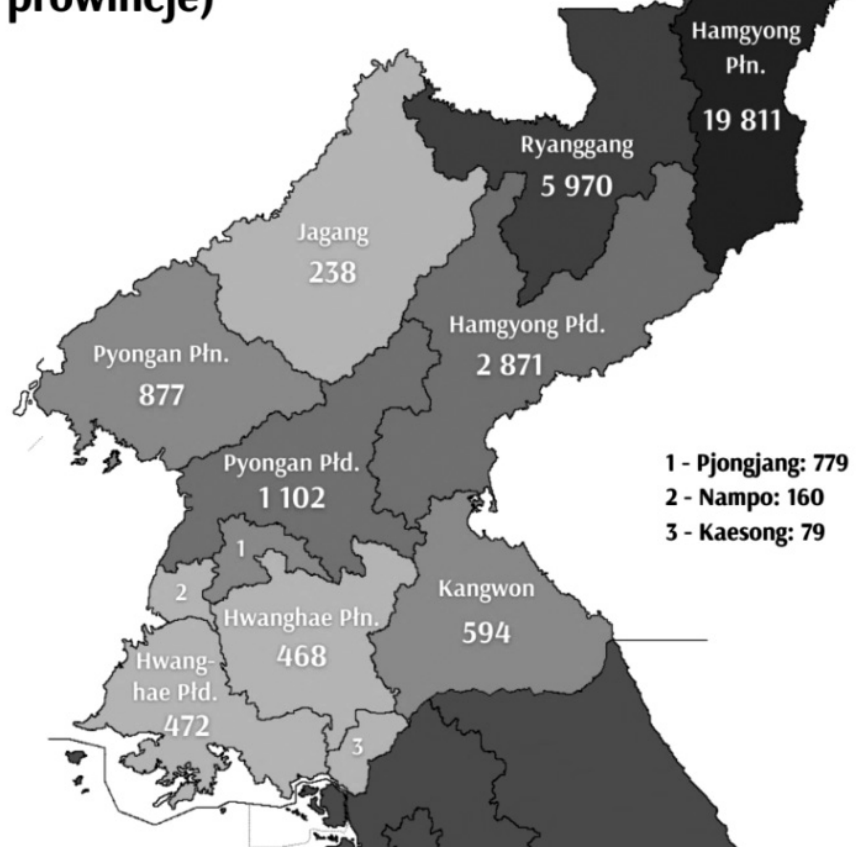

Mapa 1. Liczba północnokoreańskich uciekinierów (podział na prowincje)

Źródło: opracowanie własne na podstawie danych Ministerstwa Zjednoczenia Korei Południowej. Pobrane z: https://www.unikorea.go.kr/ eng_unikorea/relations/statistics/defectors/.

z nich różnymi sposobami pokonuje kilka tysięcy kilometrów, by dotrzeć do państw takich jak Wietnam, Tajlandia czy Mongolia, gdzie znajdują się południowokoreańskie placówki dyplomatyczne i konsularne. Decydują się oni na długie i często niebezpieczne podróże, choć najbliższy konsulat Korei Południowej znajduje się w położonym ok. $180 \mathrm{~km}$ od granicy Chin z KRL-D Shenyang, a ambasada w Pekinie. Powodem jest ścisła kontrola południowokoreańskich placówek przez chińskie służby, szczególnie tych położonych blisko granicy chińsko-północnokoreańskiej. 


\section{Proces adaptacyjny w Korei Południowej}

Zgodnie z Konstytucją Republiki Korei (Korei Południowej) każdy obywatel KRL-D jest także obywatelem Korei Południowej, a rząd jest zobowiązany do ich ochrony (Konstytucja Republiki Korei, 1987). Północnokoreańscy uciekinierzy są nazywani saeteomin (pol. nowi osadnicy) lub bukhanitaljumin (pol. mieszkańcy, którzy wyrzekli się Korei Pótnocnej), przy czym druga nazwa jest tą oficjalną, używaną przez władze Korei Południowej (Oh et al., 2012, s. 57-58).

By zapewnić uciekinierom odpowiednią pomoc, w 1997 roku przyjęto ustawę o ochronie i wsparciu w osiedleniu dla północnokoreańskich uchodźców (która była następnie kilkunastokrotnie nowelizowana). Na jej podstawie zapewnia się m.in. ochronę zatrudnienia na okres minimum trzech lat, pomoc medyczną, emerytury dla osób powyżej 60 roku życia, ułatwiony dostęp do edukacji czy też w niektórych przypadkach ochronę ze strony Narodowej Służby Wywiadu, gdy istnieje obawa, że życie uciekiniera jest zagrożone (Ustawa o ochronie i wsparciu w osiedleniu dla północnokoreańskich uchodźców ${ }^{1997)}$.

Gdy uciekinier dotrze do placówki dyplomatycznej bądź konsularnej Korei Południowej, otrzymuje natychmiastową pomoc. Zostaje zakwaterowany na terenie misji lub w tymczasowym schronisku na terenie państwa, gdzie się znajduje (Korea Hana Foundation, ${ }^{2017)}$. Wtedy też weryfikuje się tożsamość uciekiniera, by potwierdzić, że faktycznie uciekł on z KRL-D. Proces ten może trwać od kilku dni do nawet kilku tygodni. Po zatwierdzeniu uciekinierzy mogą przylecieć do Korei Południowej. Wtedy też otrzymują ze względów bezpieczeństwa nową tożsamość. Trafiają oni najpierw do siedziby Narodowej Służby Wywiadu, gdzie są przesłuchiwani. Stamtąd kierowani są do ośrodka Hanawon ${ }^{5}$. Tam w ciągu 12-tygodniowego pobytu biorą udział w zajęciach, które mają pozwolić im szybciej dostosować się do życia w południowokoreańskim społeczeństwie. Dotyczą one systemu politycznego i gospodarczego Korei Południowej, jej społeczeństwa, języka, technologii - m.in. używania Internetu, komputerów i smartphone’ów, zakładania konta

5 To specjalistyczny ośrodek powstały w 1999 roku na podstawie Ustawy o ochronie i wsparciu w osiedleniu dla północnokoreańskich uchodźców. 
bankowego, obsługi bankomatów i biletomatów (Hegarty, 2013). W trakcie tych tygodni uciekinierzy z Korei Północnej otrzymują także wsparcie psychologów i psychiatrów. Pomaga się im również w zakresie poszukiwania pracy oraz szkoleń, a także zapisów do szkół lub na uczelnie (Sohn, 2013, s. 113).

Po zakończeniu programu w ośrodku uciekinierzy zaczynają adaptować się do życia w Korei Południowej. Wciąż otrzymują duże wsparcie od rządu i wielu organizacji pozarządowych, w tym opłacanie wynajmu mieszkań czy czesnego w szkołach, jednak od tego momentu sami podejmują decyzje dotyczące swojego życia. Niektórzy ze względów ich bezpieczeństwa są także objęci ochroną ze strony oficerów policji lub Narodowej Służby Wywiadu. Na dzień 01.03.2021 takich osób jest 900 (Ministerstwo Zjednoczenia, 2021b).

Po dotarciu do południowokoreańskich placówek dyplomatycznych lub konsularnych i etapie weryfikacji uciekinierzy z KRL-D trafiają do Korei Południowej, gdzie najpierw przebywają w specjalnie dostosowanym do nich ośrodku, a następie rozpoczynają życie w południowokoreańskim społeczeństwie. W zależności od uwarunkowań zewnętrznych (tj. najbliższe otoczenie, miejsca pracy lub nauki), a także uwarunkowań indywidualnych każdego uciekiniera (takich jak jego otwartość czy umiejętności społeczne) proces adaptacyjny może trwać od kilku miesięcy do kilku lat, a w niektórych przypadkach może się nigdy w pełni nie zakończyć.

\section{Główne problemy adaptacyjne}

Uciekinierzy z KRL-D mieszkający na terenie Korei Południowej w trakcie swojego procesu adaptacyjnego napotykają na szereg trudności natury psychologicznej, gospodarczej, językowej, polityczno-prawnej, edukacyjnej i społecznej. Jednocześnie należy podkreślić, że w niektórych aspektach bariery są zbyt duże do pokonania, a w innych z kolei północnokoreańscy uciekinierzy odnotowują sukcesy. Należy mieć także na względzie, że północnokoreańscy uciekinierzy to nie jest jednolita grupa osób. Różnią się oni pochodzeniem i wcześniejszym życiem w Korei Północnej, umiejętnościami społecznymi, wiekiem czy wykształceniem. To wszystko wpływa na to, że proces adaptacyjny na terenie Korei Południowej u każdego z nich będzie przebiegać inaczej. 
Trauma związana z życiem w KRL-D oraz ucieczką z ojczyzny prowadzi do wielu zaburzeń i problemów ze zdrowiem psychicznym u północnokoreańskich uciekinierów. Życie w państwie, gdzie obywatele są nieustannie inwigilowani przez władze, brakuje pożywienia, oraz głód, który nierzadko prowadzi do śmierci, jest powszechnym zjawiskiem, sprawiają, że część Koreańczyków decyduje się przekroczyć nielegalnie granice własnego państwa w poszukiwaniu lepszych warunków. Ucieczka z kolei często prowadzi do poczucia winy, które utrzymuje się latami, z powodu pozostawienia członków rodziny w KRL-D i tego, co może im się stać, gdy władze dowiedzą się o nielegalnym opuszczaniu kraju - najczęściej trafiają do więzienia lub obozu, a w skrajnych przypadkach karani są nawet śmiercią. To wszystko prowadzi do występowania u uciekinierów z Północy lęków, depresji, nerwic, zaburzeń relacji międzyludzkich, braku zaufania do kogokolwiek oraz obsesji (Chung et al., 2018, s. 192-193). A te zaburzenia sprawiają z kolei, że przystosowywanie się do życia w Korei Południowej jest jeszcze trudniejsze.

Dla uciekinierów z KRL-D jednym z głównych problemów jest inny system gospodarczy. Korea Południowa to jedno z najbardziej rozwiniętych technologicznie państw na świecie, nastawione na masową produkcję i masową konsumpcję, gdzie dba się o kulturę konsumencką, a agresywny marketing nie jest niczym obcym. Dla Koreańczyka z Północy to wszystkie jest obce. W sklepach mają problemy związane z ogromem wyboru produktów, które często są dla nich nowe. Nie ufają także formie zakupów przez Internet. Czasem popadają w długi pomimo dość rozbudowanego wsparcia socjalnego (Sohn, 2013, s. 119-121). Uciekinierzy mają również trudności ze znalezieniem zatrudnienia. Według danych za 2020 rok stopa bezrobocia wśród uciekinierów jest ponad dwukrotnie wyższa niż ogólna stopa bezrobocia Korei Południowej - 7,7\% w stosunku do 3,6\% (The Database Center for North Korean Human Rights, 2020). Dlatego też pojawiają się różne pomysły ze strony polityków oraz organizacji pozarządowych jak zniwelować te rozbieżności. Na uwagę zasługuje najnowsza propozycja, przedstawiona przez Ji Seong-ho - deputowanego do Zgromadzenia Narodowego Republiki Korei i uciekiniera z KRL-D, który mieszka w Korei Południowej od kilkunastu lat. Zakłada ona szereg korzyści dla firm, które będą zatrudniać więcej niż pięciu uciekinierów z Północy (W. Jung, 2021). Poza powyższymi elementami uciekinierzy z KRL-D często mają także „poczucie niższości 
z powodu niekompetencji w zakresie wiedzy i umiejętności zawodowych" i to pomimo programów ze strony rządów południowokoreańskich ${ }^{6}$, które mają pomagać dostosowywać się do rynku pracy (Jeon et al., 2013, s. 163).

Innym, równie ważnym problemem jest język. Choć dla niektórych może brzmieć irracjonalnie, że ludzie posługujący się tym samym językiem mają problemy, by się porozumieć, to obecnie mieszkańcy obu Korei są w stanie wzajemnie się zrozumieć jedynie w 60\% (Jo, 2018). Globalizacja w Korei Południowej i jednoczesna izolacja Korei Północnej sprawiała, że uciekinierzy z KRL-D mają duże trudności w porozumiewaniu się. Do tego dochodzą także różnice akcentu. Dlatego też od wielu lat trwają prace nad Gyeoremal-keunsajeon (pol. wielki słownik języka narodowego), który byłby de facto słownikiem koreańsko-koreańskim (D. Jung, 2019). Z powodu zmieniającej się często sytuacji na Półwyspie Koreańskim jego opracowywanie było kilkukrotnie zawieszane. Zgodnie ze słowami ministra zjednoczenia Korei Południowej Lee In-younga z dnia 22 lutego 2021 roku słownik jest ukończony w 81 procentach (Yonhap, 2021). Uciekinierzy z KRL-D od kilku lat mają możliwość korzystania $\mathrm{z}$ aplikacji UniVoca na smartphone’y, która za pomocą aparatu tłumaczy obce im południowokoreańskie słowa (UniVoca, 2018). Ułatwia ona codzienne życie i pomaga w rozumieniu języka. Warto podkreślić, że w pracach nad aplikacją brali udział także sami północnokoreańscy uciekinierzy (Ottosen, 2021).

Także system polityczny Korei Południowej jest swego rodzaju wyzwaniem dla północnokoreańskich uciekinierów. Wolność słowa, wolność wyboru partii i kandydata w wyborach, możliwość organizowania protestów przeciwko decyzjom władz państwowych czy samorządowych dla Koreańczyków z Północy jest jednocześnie fascynująca i obca. „Dojrzenie” do demokracji u niektórych może trwać latami. Brakuje jednak badań, które analizowałyby choćby partycypację uciekinierów z KRL-D w wyborach (Hur, 2018, s. 98). Niemniej jednak niektórzy Koreańczycy z Północy wykorzystują możliwość swobodnego wyrażania własnych słów do działań na rzecz mieszkańców KRL-D, jak i uciekinierów, którzy już znajdują się na terenie Korei

6 Wśród takich programów można wyróżnić m.in. kształcenie zawodowe współorganizowane przez Ministerstwo Zatrudnienia i Pracy czy indywidualne doradztwo zawodowe oraz wsparcie przy zakładaniu działalności gospodarczej, czym zajmuje się organizacja Korea Hana Foundation, afiliowana przy Ministerstwie Zjednoczenia. 
Południowej. Przykładem jest tutaj Free North Korea Radio, założone w 2004 roku przez uciekinierów. Celem jest podnoszenie świadomości obywateli Korei Południowej nt. sytuacji w KRL-D oraz próby kontaktu z mieszkańcami Północy (Free North Korea Radio, ${ }^{2019}$. Co więcej, uciekinierzy z KRL-D zaczynają być coraz bardziej aktywni politycznie, tak jak wspomniany już wyżej Ji Seong-ho. W 2012 roku Cho Myung-chul został pierwszym uciekinierem, który uzyskał mandat deputowanego w południowokoreańskim Zgromadzeniu Narodowym. W 2020 roku wybory w jednym z okręgów w Seulu wygrał Thae Yong-ho - były północnokoreański dyplomata, który uciekł w 2016 roku (Bicker, 2020). W ubiegłym roku powstała także Partia Zjednoczenia Północ-Południe, która składa się wyłącznie z Koreańczyków, którzy uciekli z KRL-D (Stangarone, 2020). I choć nie przekroczyła ona progu wyborczego, to sam jej start w wyborach parlamentarnych zyskał w Korei Południowej duży rozgłos.

Pierwsze problemy u młodszych uciekinierów pojawiają się, gdy zaczynają uczęszczać do południowokoreańskich szkół. System nauczania znacznie się różni się od tego, który znali w Korei Północnej. Zazwyczaj ich oceny są niższe niż innych uczniów. Dzieje się tak nawet pomimo zajęć przygotowawczych w szkołach przystosowanych specjalnie dla młodszych uciekinierów, takich jak Hankyoreh High School. Z racji tego, iż od przekroczenia granicy KRL-D do przyjazdu do Korei Południowej mija wiele miesięcy, a czasem nawet i lat, trafiają oni do niższych klas, co powoduje problemy z nawiązywaniem przyjaźni. Do tego dochodzą bariery językowe oraz nierzadko dokuczanie i prześladowania. Wszystko to powoduje, że wskaźnik porzucania nauki przez uciekinierów z KRL-D jest znacznie wyższy niż u ich południowokoreańskich rówieśników (Sung, Go, 2014, s. 8-9). Co więcej, uczniowie pochodzący z Korei Północnej znacznie częściej mają myśli samobójcze, niż ci urodzeni na Południu - odsetek ten wynosi 28\% w stosunku do $15 \%$ (Choi, Kim, 2020, s. 7).

Jeszcze innym problemem, który dotyka szczególnie uczniów i studentów, jest brak nauki języka angielskiego w KRL-D. Północnokoreańscy uciekinierzy często uważają swoją znikomą znajomość tego języka za jedną z najtrudniejszych przeszkód w zdobywaniu wykształcenia w Korei Południowej. W tym miejscu należy napisać o zjawisku tak zwanej „angielskiej gorączki”, jaka ma miejsce w tym kraju. Znajomość języka angielskiego jest uznawana 
za niezbędny element do zdobycia średniego i wyższego wykształcenia oraz pracy. To powoduje, że angielski jest już nauczany w przedszkolach (Kim, 2016, s. 3-4). Co więcej, wiele słów pochodzących z języka angielskiego zostało zaadaptowanych do języka koreańskiego. Naturalnym więc jest to, że Koreańczycy z Północy muszą włożyć wiele pracy, by nadrabiać zaległości językowe. Często uczęszczają oni na dodatkowe zajęcia, które mają im w tym pomóc.

Dyskryminacja ze strony Koreańczyków z Południa to także poważne zagadnienie. Szacuje się, że doświadcza jej nawet 20\% uciekinierów z Północy (The Korea Times, 2020). Często są oni traktowani jako „obcy”. W rezultacie doświadczają nieufności, niesprawiedliwego traktowania, ostracyzmu, a nawet jawnej wrogości (Sung, Go, 2014, s. 10-11). Brak akceptacji ze strony otoczenia prowadzi do kryzysów tożsamości u uciekinierów - nie są już obywatelami Korei Północnej, ale nie czują się także pełnoprawnymi obywatelami Korei Południowej.

Przedstawione powyżej informacje wskazują, że północnokoreańscy uciekinierzy zmagają się z wieloma problemami adaptacyjnymi w Korei Południowej. Dotykają one niemal każdego aspektu ich życia. Jedni poradzą sobie z nimi lepiej, inni gorzej - dużo zależy od ich indywidualnych predyspozycji. Dla jednego uciekiniera barierami nie do pokonania będą kwestie językowe, inny z kolei szybko sobie z nimi poradzi, ale za to głównym problemem dla niego będą trudności związane z odmiennym systemem gospodarczym, niż ten, jaki znał z Korei Północnej.

\section{Historie uciekinierów}

W tej części przedstawione zostały historie kilku północnokoreańskich uciekinierów, którzy zdecydowali się podzielić własnymi przeżyciami związanymi z samą ucieczką, jak i adaptacją w Korei Południowej. Dobrano te historie tak, by były jak najbardziej zróżnicowane - zarówno w kwestii samej historii i trasy ich ucieczki z Korei Północnej, jak i również i ich obecnego życia na terenie Korei Południowej. Ma to na celu podkreślenie, że północnokoreańscy uciekinierzy nie są grupą jednorodną.

Jun Heo dwukrotnie uciekał z Korei Północnej. W 2006 roku uciekła najpierw jego matka, a on sam kilka miesięcy później dzięki przekupionym 
strażnikom granicznym udał się do Chin. Miał wtedy 14 lat.W Pekinie, gdzie przebywał wraz z grupą innych uciekinierów, został jednak złapany przez chińską policję i deportowany do KRL-D. Najpierw trafił na trzy miesiące do obozu pracy, a następnie otrzymał areszt domowy. W 2008 ponownie uciekł z kraju i przez dwa lata ukrywał się w Szanghaju. Do Korei Południowej przyleciał w listopadzie 2010 roku. Obecnie studiuje politologię i próbuje prowadzić normalne życie. Nie ma jednak kontaktu z matką, która uciekła przed nim, a także z ojcem, który pozostał w KRL-D (Humans of North Korea, 2020a).

Un Jeong uciekła w 2008 roku jako nastolatka. Gdy była dzieckiem, widziała, jak jej babcia umiera z głodu. Przed wyjściem zostawiła rodzicom list. Początkowo myślała, że wróci do KRL-D po kilku miesiącach, gdy zarobi pieniądze, które pomogą jej rodzinie. Po przekroczeniu granicy z Chinami została sprzedana przez północnokoreańskiego przemytnika. W ciągu następnych siedmiu miesięcy była sprzedawana jeszcze trzy razy, aż w końcu udało jej się uciec. Udała się do Wietnamu, a stamtąd do Kambodży, gdzie poprosiła o pomoc w ambasadzie Korei Południowej. Po czterech latach życia na Południu udało jej się nawiązać kontakt z bliskimi. Za pomocą łapówek wyciągnęła rodziców i rodzeństwo z KRL-D. Obecnie żyją razem w Seulu (Humans of North Korea, 2020b).

John Zheng także uciekał dwa razy. Pierwszy raz w 1998 roku razem z matką, gdy miał 8 lat. Zostali jednak złapani, a on sam trafił na miesiąc do obozu koncentracyjnego. Drugi raz uciekł jako nastolatek, jednak nie chciał opisywać dokładnej podróży. Mimo upływu wielu lat wciąż nie czuje się jak pełnoprawny obywatel Korei Południowej - pozostał mu akcent, a ludzie uznają go za obcokrajowca. Obecnie boi się, że nie będzie miał wystarczająco dużo pieniędzy, gdyby rodzina, która pozostała w KRL-D się z nim skontaktowała, by pomógł im uciec (Humans of North Korea, 2020c).

Z Korei Północnej w 2005 roku uciekł najpierw ojciec Park Yu-Sunga, a gdy zamieszkał w Korei Południowej, rozpoczął starania, by ściągnąć żonę i syna. W 2007 roku Yu-Sung wraz z matką przekroczyli rzekę Tumen. W grupie kilku osób przejechali całe Chiny, nielegalnie przekroczyli granicę z Laosem, a następnie udali się do Tajlandii. W Bangkoku mieszkali przez kilka miesięcy, a do Korei Południowej przylecieli w 2008 roku. Yu-Sung rozpoczął naukę w Hankyoreh High School (szkoła dla dzieci z KRL-D), 
a po sześciu miesiącach przeniósł się do zwykłego liceum. Obecnie kończy studia filmowe (Humans of North Korea, 2019).

Historia Gyeong Hoona jest nieco inna - on sam urodził się już na terenie Chin (matka uciekła z KRL-D). Dorastał wśród osób, które na co dzień posługiwały się językiem chińskim. Gdy wraz z matką przyjechali do Korei Południowej, miał duże problemy z porozumiewaniem się z rówieśnikami. W szkole był gnębiony przez inne dzieci, które przezywały go „commie” (pogardliwe wyrażenie na Koreańczyków z Północy, oznaczające „komucha”). Z tego powodu często zmieniał szkoły, co jednak nie rozwiązywało problemu dyskryminacji. Mimo upływu wielu lat wstydzi się mówić o swoim prawdziwym pochodzeniu, boi się odrzucenia (Humans of North Korea, 2020d).

\section{Zakończenie}

Należy być świadomym, że mieszkańcy Korei Północnej, którzy decydują się uciec z własnego kraju, zostawiają za sobą wszystko - ojczyznę, dom, rodzinę, przyjaciół. Ich podróż do Korei Południowej nie trwa kilku dni, a ciągnie się miesiącami, a nawet latami. Gdy już znajdą się na terytorium Południa, zaczyna się dla nich kolejny, długotrwały proces - proces adaptacji do innego świata i społeczeństwa. Dla wielu uciekinierów proces ten nigdy się nie skończy i zawsze będą tymi „innymi”. I choć należą do obu Korei, bo na Północy się urodzili, a na Południu żyją, to jednocześnie nie należą do żadnej z nich.

Koreańczykowi z KRL-D znacznie lepiej żyje się na Południu i ma przede wszystkim wolność, której brakuje na Północy, to jednak napotyka on wiele trudności w odnalezieniu się w nowej rzeczywistości (Choi, 2018, s. 93). Często nie potrafi zrozumieć, jak działa gospodarka oparta na zasadach wolnego rynku. Wiele technologii także jest mu obca. Co więcej, ma duże problemy w komunikacji, które wynikają nie tylko z różnic językowych, ale także traumy, która powoduje brak zaufania do kogokolwiek. Do tego dochodzi dyskryminacja ze strony części obywateli Korei Południowej, a u młodszych uciekinierów także problemy w szkole i na studiach.

Istnieje wiele barier, które utrudniają pełną adaptację do życia na terenie Korei Południowej, zarówno natury gospodarczej, językowej, polityczno-prawnej, edukacyjnej jak i społecznej, które de facto dotykają niemal 
każdego aspektu życia uciekiniera. Jednakże istnieją także sytuacje, które można określić mianem sukcesów w procesie adaptacyjnym. Mowa tu choćby o współtworzeniu przez uciekinierów aplikacji UniVoca czy powstaniu radia Free North Korea. Wiele zależy także od indywidualnych predyspozycji samego uciekiniera. Co więcej, część Koreańczyków z KRL-D, mieszkających na Południu wykorzystuje swoje doświadczenie, by nie tylko pomagać innym uciekinierom, ale także, by podnosić świadomość wśród południowokoreańskiego na temat sytuacji panującej na północ od 38. równoleżnika. Angażują się społecznie i politycznie, zasiadają w południowokoreańskim parlamencie, a nawet zakładają własne partie. Ich przykłady pokazują, że uciekinier z Korei Północnej może nie tylko zaadaptować się do życia w Korei Południowej, ale także stać się aktywnym obywatelem.

Niewątpliwe programy wsparcia dla uciekinierów ze strony władz Korei Południowej są bardzo rozbudowane i obejmują wiele aspektów adaptacji, począwszy od 12-tygodniowego programu przygotowującego do życia na terenie Południa, poprzez szkolenia, po finansowe wsparcie. Jednak patrząc na analizowane w niniejszym artykule problemy, być może należałoby zmienić strategię pomocy, by była ona bardziej skuteczna, nastawiona nie tylko na wsparcie materialne, ale w większym stopniu także i psychologiczne. Być może należałoby też zapewnić większe wsparcie w zakresie języków, zarówno koreańskiego, jak i angielskiego, poprzez bezpłatne dodatkowe zajęcia. Warto rozważyć także bardziej indywidualne podejście do każdego uciekiniera - stworzyć stanowisko mentora albo tutora, który byłby do dyspozycji uciekiniera przez co najmniej kilka pierwszych miesięcy adaptacji w Korei Południowej, wspierał go i pomagał w codziennym życiu. Istotna jest również kwestia dyskryminacji ze strony południowokoreańskiego społeczeństwa. Jednakże temat ten jest pomijany przez południowokoreańskie władze i brakuje systemowego podejścia w jego zwalczaniu. $\mathrm{Z}$ roku na rok liczba północnokoreańskich uciekinierów będzie się coraz bardziej powiększać, więc kwestii tej nie można ignorować. Dlatego też należałoby wprowadzić programy ukierunkowane na Koreańczyków urodzonych na Południu, których celem byłoby uświadomienie społeczeństwa, że uciekinierzy z KRL-D to nie „obcy”, a rodacy, którzy urodzili się poza granicami kraju, i którzy potrzebują wsparcia w swoim procesie adaptacyjnym. Powinny być one skierowane nie tylko do pełnoletnich obywateli Korei Południowej, ale 
także, i co może nawet istotniejsze, do uczniów, ponieważ uciekinier, który nie poradzi sobie $\mathrm{z}$ adaptacją $\mathrm{w}$ młodszym wieku, będzie napotykał wiele trudności także w dorosłym życiu.

Północnokoreańscy uciekinierzy mieszkający na Południu z roku na rok stają się coraz liczniejszą grupą, która coraz częściej będzie pojawiać się w dyskursie publicznym. Dotyczyć to będzie najprawdopodobniej nie tylko ich aktywności, ale także w kontekście dyskusji nad programami dla północnokoreańskich uciekinierów, które mają na celu wsparcie ich w procesie adaptacji. Wspominani wcześniej Ji Seong-ho, Cho Myung-chul czy Thae Yong-ho, którzy zostali aktywnymi politykami po zamieszkaniu w Korei Południowej, pokazują, że uciekinierzy chcą otwarcie o sobie mówić. Dowodzi tego także powstanie w ubiegłym roku Partii Zjednoczenia Północ-Południe, składającej się wyłącznie z północnokoreańskich uciekinierów. I choć nie przekroczyła ona progu wyborczego, to położyła fundamenty pod przyszłą działalność polityczną uciekinierów, którzy mogą nie tylko działać na rzecz własnej grupy, ale także potencjalnie zaangażować się w tworzenie oficjalnej polityki Korei Południowej wobec KRL-D, a także brać udział w dialogu międzykoreańskim.

\section{LIC. NATALIA MATIASZCZYK}

Wydział Studiów Międzynarodowych i Politologicznych

Uniwersytet Łódzki

ul. Składowa 43, 91-358 Łódź

natalia.matiaszczyk@gmail.com

\section{Bibliografia}

Bicker, L. (2020, 16 kwietnia). North Korean defector becomes first to win South Korea parliamentary seat. Pobrane z: https://www.bbc.com/news/world-asia-52305447.

Choi, G. (2018). North Korean Refugees in South Korea: Change and Challenge in Settlement Support Policy. The Korean Journal of International Studies, 16(1), 77-98.

Choi, S., Kim, K. (2020). We Don't Belong Here: Adolescents of North Korean Refugee Families and Their Suicidal Behaviors. International Migration, 58(6), 232-246.

Chung, Ch. et al. (2018). Health-seeking experience of North Korean women defectors in South Korea. Public Health Nurs, 35(3), 192-201. 
Colin, S. (2003). A border opening onto numerous geopolitical Issues. The Yanbian Korean Autonomous Prefecture. China Perspectives, 48(4), 1-25.

Free North Korea Radio (2019). Pobrane z: http://www.fnkradio.com/page/intro.html.

Hajek, D. (2017, 5 lipca). Watching Foreign Movies Is Illegal In North Korea, But Some Do It Anyway. Pobrane z: https://www.npr.org/2017/07/05/534742750/watching-foreign-movies-is-illegal-in-north-korea-but-plenty-do-it-anyway?t=1620237018570.

Hegarty, S. (2013, 22 kwietnia). North Korea: Defectors adjust to life abroad, „BBC”, 22 kwietnia 2013, Pobrane z: https://www.bbc.com/news/magazine-22209894.

Human Rights Watch. (2006). A Matter of Survival: The North Korean Government's Control of Food and the Risk of Hunger. Pobrane z: https://www.refworld.org/do$\mathrm{cid} / 45 \mathrm{~d} 2 \mathrm{f} 9 \mathrm{a} 62 . \mathrm{html}$.

Humans of North Korea. (2019, 22 marca). Real Story Escaping From North Korea. Pobrane z: https://www.youtube.com/watch? $\mathrm{v}=$ stjMskM-gOo\&ab_channel= HumansofNorthKorea.

Humans of North Korea. (2020a, 1 marca). The story of my life - From hell to heaven. Pobrane z: https://www.youtube.com/watch?v=SjJc3ge3mqw\&ab_channel=Humans ofNorthKorea.

Humans of North Korea. (2020b, 7 czerwca). This North Korean Girl Was Sold Three Times in China. Pobrane z: https://www.youtube.com/watch?v=3n3tRRL4RPw\&ab_ channel=HumansofNorthKorea.

Humans of North Korea.(2020c,21 czerwca).Escape North Korea Twice. Pobrane z: https:// www.youtube.com/watch?v=3A2p0vVP-Iw\&ab_channel=HumansofNorthKorea.

Humans of North Korea. (2020d, 10 czerwca). N. Korean Being High School Student in S. Korea. Pobrane z: https://www.youtube.com/watch?v=iXP6ivr-gRI\&ab _channel=HumansofNorthKorea.

Hur, A. (2018). Adapting To Democracy: Identity And The Political Development Of North Korean Defectors. Journal of East Asian Studies, 18(1), 97-115.

Jeon, W. et al. (2013). A 7-Year Follow-Up Study on the Mental Health of North Korean Defectors in South Korea. Journal of Traumatic Stress, 26(1), 158-164.

Jo, H. (2018, 5 sierpnia), Unified dictionary aims to reduce 70-year language gap between two Koreas. Pobrane z: http://www.koreaherald.com/view.php?ud=20180805000191. Jung, D. (2019, 9 października). PM highlights inter-Korean dictionary project on Hangeul Day. Pobrane z: https://www.koreatimes.co.kr/www/nation/2020/08/103_276879. html.

Jung, W. (2021, 5 stycznia). Defector unemployment rates doubled in 2020. Now, a new bill is trying to help. Pobrane z: https://www.nknews.org/2021/01/defector -unemployment-rates-doubled-in-2020-now-a-new-bill-is-trying-to-help/.

Kim, M. (2016). A North Korean Defector's Journey Through the Identity-Transformation Process. Journal of Language, Identity \& Education, 15(1), 3-16.

Konstytucja Republiki Korei (1987). Pobrane z: https://elaw.klri.re.kr/eng_service/ lawView.do?hseq=1\&lang=ENG.

Korea Hana Foundation. (2017). Settlement Support Process. Pobrane z: https://northkoreanrefugee.org/eng/info_on_nkrefugee/flow_chart.jsp.

Life Funds for North Korean Refugees (2009). Pobrane z: http://www.northkoreanrefugees.com/about/. 
Oh, J. et al. (2012). Migration Profile of the Republic of Korea. Goyang: IOM.

Ottosen, S. (2021, 22 października). Univoca Translation App Helps North Koreans. Pobrane z: https://borgenproject.org/univoca/.

Marszałek-Kawa, J. (red.). (2009). Spotkania polsko-koreańskie. Toruń: Wydawnictwo Adam Marszałek.

Marszałek-Kawa, J., Kinelski, G. (2020). Współczesne bezpieczeństwo regionu Azji i Pacyfiku. Wybrane problemy. Toruń: Wydawnictwo Adam Marszałek.

Park, H. (1996). Segyehwa: Globalization and Nationalism in Korea. The Journal of the International Institute, 4 (1), Pobrane $\mathrm{z}$ : https://quod.lib.umich.edu/j/ jii/4750978.0004.105/--segyehwa-globalization-and-nationalism-in-korea?rgn=main;view $=$ fulltext.

Shin, M. (2020, 29 października). North Korea's Elite Defectors. Pobrane z: https://thediplomat.com/2020/10/north-koreas-elite-defectors/.

Sohn, S. (2013). Living in a Consumer Society: Adaptation Experiences of North Korean Youth Defectors in South Korea. Asian and Pacific Migration Journal, 2(1), 109-131.

Sonn, Ch. (2002). Immigrant Adaptation: Understanding the Process Through Sense of Community. W: A. Fisher, Ch. Sonn, B. Bishop (red.). Psychological Sense of Community: Research, Applications, and Implications (205-222). Nowy Jork: Springer.

Stangarone, T. (2020, 9 kwietnia). The North Korean Subplots in South Korea's National Assembly Elections. Pobrane z: https://thediplomat.com/2020/04/ the-north-korean-subplots-in-south-koreas-national-assembly-elections/.

Sung, J., Go, M. (2014). Resettling in South Korea: Challenges for Young North Korean Refugees, Seul: Asan Institute for Policy Studies.

The Database Center for North Korean Human Rights (NKDB). (2020, 30 grudnia). 2020 Economic and Social Integration of North Korean Defectors. Pobrane z: http:// www.nkdb.org/en/news/notice_list.php?board=notice_en\&act=view\&no=141\&page $=1 \&$ search_mode $=\&$ search_word=\&cid=\&goUrl=/en/news/notice_list.php.

The Korea Times. (2020, 26 lutego). One in five North Korean defectors experience discrimination in South Korea: poll. Pobrane z: https://www.koreatimes.co.kr/www/ nation/2020/02/103_284113.html.

통일부 [Ministerstwo Zjednoczenia]. (2021a). 북한이탈주민정책. 최근현황 [Polityka wobec pótnocnokoreańskich uciekinierów. Stan najnowszy]. Pobrane z: https://www. unikorea.go.kr/unikorea/business/NKDefectorsPolicy/status/lately/.

통일부 [Ministerstwo Zjednoczenia]. (2021b). 지원제도 [System wsparcia]. Pobrane z: https://www.unikorea.go.kr/unikorea/business/NKDefectorsPolicy/settlement/ System/.

UniVoca. (2018). Pobrane z: https://apkpure.com/univoca/kr.co.pengtai.guldongmu.

Ustawaoochronieiwsparciuwosiedleniudlapółnocnokoreańskichuchodźców (1997).Pobrane z: https://elaw.klri.re.kr/eng_mobile/viewer.do?hseq=47875\&type=part\&key=38.

Yonhap. (2021, 22 lutego). Unification minister calls for early resumption of inter-Korean dictionary project. Pobrane z: https://en.yna.co.kr/view/ AEN20210222006100325? section=nk/nk. 